\title{
Knowledge Domain of Bt Cotton Cultivation Practices by the Bhoochetana Programme Beneficiaries
}

\author{
B. Nagesh $^{1 *}$, S.K. Meti ${ }^{2}$ and G.N. Maraddi ${ }^{3}$ \\ ${ }^{1}$ Farm Management/ Farm Superintendent, Agricultural Research Station, Guladalli Koppal, \\ UAS, Raichur, Karnataka, India \\ ${ }^{2}$ Department of Agricultural Extension Education, University of Agricultural Sciences, \\ Raichur-584104, Karnataka, India \\ ${ }^{3}$ Agricultural Extension Education Centre, Lingasugur, University of Agricultural Sciences, \\ Raichur-584104, India \\ *Corresponding author
}

A B S T R A C T

The research study was conducted on impact of training programme on knowledge, perception and attitude of stakeholders towards Bhoochetana programme. The Raichur, Koppal and Bellary districts were purposively selected based on their maximum area under

\section{Keywords}

Bt cotton, Knowledge domain, Bhoochetana programme \& Relationship analysis

Article Info

Accepted: 24 September 2018 Available Online: 10 October 2018 cotton cultivation. The random sampling procedure is being used to identify 180 beneficiaries. The ex-post-facto research design is used in this study. It was revealed that cent per cent of the respondents had knowledge about the improved hybrids which were suited to their region. Majority $(93.89 \%)$ of the respondents had knowledge about sowing time followed by sowing method $(92.78 \%)$, recommended spacing $(91.66 \%)$, suitable soil (91.66\%), recommended seed rate $(87.22 \%)$ and duration of the crop $(76.61 \%)$ for cultivation of Bt cotton. Majority $(81.66 \%)$ of the respondents had knowledge about insect of leaf hopper followed by thrips $(63.89 \%)$ and mirid bugs $(62.22 \%)$. In case of management of diseases, majority of $(65.55 \%)$ the respondents know the management of leaf spot. The correlation analysis corroborated that the education, farming experience had positive and significant relationship of with the knowledge level of recommended practices in Bt cotton crop. Achievement motivation \& management orientation was positively and significantly correlated with the knowledge of recommended practices in Bt cotton at $0.01 \%$ level of significance.

\section{Introduction}

Globally, rainfed areas are hot-spots for poverty, malnutrition and degradation of natural resources. In our country, out of the total geographical area of 329 million ha, 143 million ha is under cultivation, out of which 108 million ha area is rainfed (75\%). Rainfed agriculture contributes about 44 per cent of the total food grain production in the country and supports 40 per cent of the population. Bulk of pulses, oil seeds, millets, coarse grains, commercial crops etc., are accounted by the rainfed agriculture. Thus, dryland holds great prospect of contributing substantially to country's food production. Unless the production from these rainfed areas increases, the real breakthrough in agriculture may not be possible. Hence, dry land development strategy is important for agriculture 
development in the state. Scanty rainfall on the one hand and high density of rainfall on the other are the major threats to the dry land agriculture. Improved crop production technologies with the efficient utilization of natural resources play an important role in increasing the dry land crop productivity and in turn production. Karnataka stands second in possessing area under rainfed agriculture after Rajasthan in the country. Crop yields in dry land areas are quite low (1-1.5 $\left.\mathrm{t} \mathrm{ha}^{-1}\right)$ which are lower by two to five folds of the yield from researchers managed plots. In this context, the Government of Karnataka has taken up an innovative science-led development initiative called Bhoochetana to harness the potential of rainfed agriculture in the state with the help of International Crops Research Institute for Semi - Arid Tropics (ICRISAT) which was launched on 23 May 2009.

More or less similar situation exists in Karnataka. Out of total cultivated area of 123.85 lakh ha, about 70 per cent of the area is rainfed. Major rainfed crops of the state are jawar, ragi, maize, minor millets, groundnut, sunflower, soybean, pigeonpea, greengram, bengalgram and fieldbean etc. It has been observed that the average yields of these crops by and large in the state are less than the national average and also averages of other states. Further, a wide gap exists in actual yield levels in the farmer's field and yields of field level demonstrations. The main responsibility of extension work lies with the Department of Agriculture. The department is striving hard to bridge the gap between the actual farmers yield and the potential yields of crops, through various extension methods. In India, the State Department of Agriculture charged with the responsibility of agricultural development has grown into mammoth service organization. The programme has completed five years. Now, it is necessary to study how the Bhoochetana programme has made an impact on knowledge level among cotton growers and relationship with their socioengineering attributes along with management $\&$ situational attributes. In this context, the present study is being conducted to assess the knowledge domain of farm beneficiaries about the improved production technologies of $\mathrm{Bt}$ cotton.

\section{Materials and Methods}

The study was conducted in Raichur, Koppal and Bellary districts of Hyderabad Karnataka during the year 2015-16 These district's were purposively selected because of maximum area under cotton is being cultivated in Hyderabad Karnataka region. The Ex-postfacto research designs were used for the study. Two talukas from each districts selected \& inturn, two villages under each talukas were selected based on the criteria of having highest area under $\mathrm{Bt}$ cotton. Again thirty cotton growers identified from each village. Thus total size constitutes 180 respondents. The standard \& structured schedule used for investigation, which is being tested in nonsample area. The systematic random sampling procedure used to finalize $\mathrm{Bt}$ cotton growers for the research.

\section{Results and Discussion}

\section{Over all knowledge status of Bhoochetana Programme beneficiaries}

It is evident from the data in Table 1 that, 47.22 per cent of the respondents had medium level of knowledge, whereas 27.78 and 25.00 per cent of respondents had low and high knowledge, respectively. Majority of the respondents studied up to high school and analysis of mass media revealed majority of respondents possessed television sets. Further, the study also revealed that most of respondents participated in extension activities like demonstrations (56.11\%), group 
meetings (45.56 \%) and krishimela (21.11\%). These factors might have contributed more for possession of medium level of knowledge of Bt cotton cultivation practices. The above findings are in confirmation with the results of studies conducted by the Maraddi and Verma (2003) and Sidram (2008).

\section{Knowledge of Bhoochetana Programme beneficiaries regarding individual cultivation practices of $\mathrm{Bt}$ cotton}

An appraisal of Table 2 revealed that, cent per cent of the respondents had knowledge about the improved hybrids which were suited to their region. Majority $(93.89 \%)$ of the respondents had knowledge about sowing time followed by sowing method (92.78\%), recommended spacing $(91.66 \%)$, suitable soil (91.66 \%), recommended seed rate $(87.22 \%)$ and duration of the crop (76.61\%) for cultivation of Bt cotton. The possible reason might be that, these practices are basic and important and cotton is commercial crop to get better yield. Regarding the quantity of FYM to be applied, 69.44 per cent of the respondents had knowledge and more than half of them $(63.89 \%)$ expressed suitable time for application of FYM was 2-3 weeks before sowing. This enables the FYM to gradually penetrate and mix with the soil. With respect to inter-cultivation 81.11 per cent of respondents had knowledge, In case of fertilizer requirement, 65.00 per cent of the respondents had knowledge, about time of nitrogen application as top dressing \& 58.33 per cent had knowledge of physiological disorder, management of flower dropping (62.22\%) use of $\mathrm{MgSO}_{4}$ to manage leaf reddening $(75.56 \%)$, in addition to herbicide $(53.89 \%)$ To get higher yield and profit, above technologies are being covered during training by Farm facilitators under Bhoochetanan programme might be the reason for above findings.

Majority (81.66 \%) of the respondents had knowledge about insect of leaf hopper followed by thrips $(63.89 \%)$ and mirid bugs $(62.22 \%)$. In case of management of diseases, majority of $(65.55 \%)$ the respondents know the management of leaf spot. While, 58.33 per cent of respondent had knowledge about rust disease management. Management of insect pest and disease is very essential in crop production, delayed operation of management leads to huge loss; this might have promoted the farmers to know more about pest and disease management. Further, the results revealed that majority of the respondents were aware of the trap and inter crop that can be taken in Bt cotton. The seeds of this crop are sold in a combi pack comprising seeds of 450 gm Bt cotton and $120 \mathrm{gm}$ non Bt cotton.

This would act as an educational tool about the trap crop as 80.00 per cent were aware of non-Bt cotton as a trap crop.

Table.1 Overall knowledge of Bhoochetana Programme beneficiaries regarding individual cultivation practices of Bt cotton

$\mathrm{n}=180$

\begin{tabular}{|c|c|c|c|}
\hline Sl. No. & Category & Frequency & Percentage \\
\hline 1 & Low $($ mean $-0.425 * \mathrm{SD})$ & 50 & 27.78 \\
\hline $\mathbf{2}$ & Medium $($ mean $\pm 0.425 * \mathrm{SD})$ & 85 & 47.22 \\
\hline $\mathbf{3}$ & High $($ mean $+0.425 * \mathrm{SD})$ & 45 & \\
\hline \\
\hline
\end{tabular}


Table.2 Knowledge domain of Bhoochetana Programme beneficiaries regarding individual cultivation practices of Bt cotton

$\mathrm{n}=180$

\begin{tabular}{|c|c|c|c|}
\hline Sl. No. & Practices & Frequency & Percentage \\
\hline \multirow[t]{5}{*}{1} & Selection of seeds & & \\
\hline & Bunny & 125 & 66.66 \\
\hline & Mallika & 158 & 87.77 \\
\hline & Vikram-5 & 105 & 58.33 \\
\hline & Dr-Brent & 93 & 51.66 \\
\hline 2 & Suitable soil type (Deep black soil) & 165 & 91.66 \\
\hline 3 & Crop duration (165-175 days) & 137 & 76.61 \\
\hline \multirow[t]{3}{*}{4} & Sowing & & \\
\hline & Time (May to July 15) & 169 & 93.89 \\
\hline & Method (Manual dibbling) & 167 & 92.78 \\
\hline 5 & Seed rate $(2.5-3 \mathrm{~kg} / \mathrm{ha})$ & 157 & 87.22 \\
\hline 6 & Spacing $(90$ x $60 \mathrm{~cm})$ & 165 & 91.66 \\
\hline \multirow[t]{3}{*}{7} & FYM application/ha & & \\
\hline & Recommended quantity (10 tonnes) & 125 & 69.44 \\
\hline & Time of application (2-3 weeks before sowing) & 115 & 63.89 \\
\hline \multirow[t]{3}{*}{8} & Recommended chemical fertilizer & & \\
\hline & NPK 120:60:60 (kg /ha) & 117 & 65.00 \\
\hline & Top dressing (30 DAS) & 105 & 58.33 \\
\hline 9 & Green manure (Sunhemp) & 68 & 37.78 \\
\hline 10 & Bio-fertilizer (Azospirillum) & 64 & 35.56 \\
\hline \multirow{3}{*}{12} & Management of physiological Disorder & & \\
\hline & Flower drop (Planofix @ 0.25ml/lit) & 112 & 62.22 \\
\hline & Leaf reddening $\left(1 \% \mathrm{MgSO}_{4}\right)$ & 136 & 75.56 \\
\hline 13 & Intercultivation (2-3 times) & 146 & 81.11 \\
\hline 14 & Herbicide application (Pendimethalin 30EC, ) & 97 & 53.89 \\
\hline \multirow[t]{4}{*}{15} & Management of major insect pests & & \\
\hline & Leaf hopper (Regent @ 1ml / lit) & 147 & 81.66 \\
\hline & Thrips (Regent or monocrotophos @2ml / lit) & 115 & 63.89 \\
\hline & Mirid bug (Monocrotophos/profinophos@ 2ml / lit) & 112 & 62.22 \\
\hline \multirow[t]{3}{*}{16} & Management of Major Diseases & & \\
\hline & $\begin{array}{l}\text { Leaf spot (Bavistin / Mancozeb / Copper oxy } \\
\text { chloride @ 2gm/lit) }\end{array}$ & 118 & 65.55 \\
\hline & Cotton rust (Carboxin / captan @ 2gm / lit) & 105 & 58.33 \\
\hline \multirow[t]{4}{*}{17} & Intercropping & & \\
\hline & Chilli & 132 & 73.33 \\
\hline & Pigeonpea & 106 & 58.89 \\
\hline & Cowpea & 98 & 54.44 \\
\hline \multirow[t]{4}{*}{18} & Trap crop cultivation & & \\
\hline & Non Bt & 144 & 80.00 \\
\hline & Bhendi & 125 & 69.44 \\
\hline & Tomato & 115 & 63.89 \\
\hline 19 & Pheromone trap (4-5/ ha) & 71 & 39.44 \\
\hline 20 & Yield (20-25 q/ ha) & 136 & 75.56 \\
\hline
\end{tabular}


Table.3 Relationship between knowledge about Bt cotton farm beneficiaries with their independent variable

\begin{tabular}{|c|c|c|}
\hline Sl. No. & Variables & Correlation coefficient (r) \\
\hline 1 & Age & -0.025 \\
\hline 2 & Education & $0.278^{* *}$ \\
\hline 3 & Farming experiences & $0.291 * *$ \\
\hline 4 & Land holding & 0.005 \\
\hline 5 & Annual income & 0.095 \\
\hline 6 & Material possession & 0.105 \\
\hline 7 & Livestock possession & -0.104 \\
\hline 8 & Cropping intensity & 0.076 \\
\hline 9 & Extension participation & $0.238^{* *}$ \\
\hline 10 & Extension contact & 0.090 \\
\hline 11 & Social participation & 0.040 \\
\hline 12 & Mass media participation & 0.067 \\
\hline 13 & Cosmopoliteness & $0.283^{* *}$ \\
\hline 14 & Innovativeness & 0.089 \\
\hline 15 & Risk orientation & 0.101 \\
\hline 16 & Achievement motivation & $0.203^{* *}$ \\
\hline 17 & Economic motivation & $0.177^{*}$ \\
\hline 18 & Management orientation & $0.295^{* *}$ \\
\hline
\end{tabular}

$*=$ Significant at $0.05 \%$ level; $* *=$ Significant at $0.01 \%$ level; NS $=$ Non Significant

With respect to yield, majority $(75.56 \%)$ of respondents had knowledge about the yield that can be obtained from one hectare of land as it is major cash crop. It is logical to derive from the above discussion that the practices which are complex and difficult to remember are moderately known to farmers. On the other hand, the practices which are simple and traditionally practiced were known to majority farmers. The regular training provided under the Bhoochetana programme had facilitated to increase the knowledge level regarding above mentioned practices. The present findings were in accordance with the results reported by Kanavi (2000) and Budihal (2001).

Relationship between knowledge about Bt cotton farm beneficiaries with their independent variables

The perusal of the Table 3 reveals that, the education had positive and significant relationship of with the knowledge level of 
recommended practices in Bt cotton crop. The probable reason might be that the recommended practices being complex in nature could be understood better by persons having higher education level. Obviously the gain and retention of knowledge is more among the educated people and they become more receptive to the innovative compare the less educated or illiterates farmers. The findings were in consonance with the research findings of Tippeswamy (2007) and Hinge (2009), who found that there was a significant and positive relationship between education and knowledge level. Farming experience exhibited positive and significant relationship with the knowledge level of the respondents. Farmers having greater farming experience (more number of years) understand better about practices. This finding is in close agreement with the findings of Nimje et al., (1990) in respect of recommended practices. There was significant association between extension participation and knowledge of recommended practices. The participation in extension activities provides opportunities for contrived experiences and serves as reinforcement in gaining knowledge about recommended practices prevailing in other region or locality. The findings are in conformity with the findings of Kanavi (2000) and Rathod (2005). Achievement motivation was positively and significantly correlated with the knowledge of recommended practices in Bt cotton at $0.01 \%$ level of significance. The excellence or perfection is one determining the achievement motivation and to achieve destination one need to take adequate and meticulously care to achieve success maximising and sustaining yield and income. Hence, achievement motivation was found to be significantly correlated with the knowledge of recommended practices. The results are in line with the findings of Chandregowda (1996) and Resmy (1998). It was also observed that management orientation was positively and significantly correlated with the knowledge of recommended practices in Bt cotton at $0.01 \%$ level of significance.

The empowerment of knowledge among beneficiaries is being observed due to various training programme conducted under bhoochetana programme. It was concluded that improvement in the knowledge domain of beneficiaries on production technologies like suitability of $\mathrm{Bt}$ cotton genotype, spacing, water management, pest \& disease management is noticed. Hence this enrichment of knowledge is being influenced by various independent variables of beneficiaries.

\section{References}

Budihal, R. A., 2001, Utilization pattern of cotton production technology by farmers of northern Karnataka. Ph. D. Thesis, Univ. Agric. Sci., Dharwad, Karnataka (India).

Chandregowda, M. J. and Jayaramaiah, M., 1996, Integrated nutrient management in rice farming under four rice ecosystems. Organic Farming and Sustainable Agriculture Abstracts, National Seminar, October 9-11 organized by Univ. of Agric. Sci., Bangalore.

Hinge, R. B., 2009, Diffusion and adoption of wine grape production technology in Maharashtra. M. Sc (Agri.) Thesis, Univ. Agric. Sci., Dharwad, Karnataka (India).

Kanavi, V. P., 2000, A study on the knowledge and adoption behaviour of sugarcane growers in Belgaum district of Karnataka. M. Sc. (Agri.) Thesis, Univ. Agric. Sci., Dharwad (India).

Maraddi, G. N., 2006, An analysis of sustainable cultivation practices followed by Sugarcane growers in 
Karnataka. Ph. D. Thesis, Univ. Agric. Sci., Dharwad, Karnataka (India).

Rathod Devaraj Naik, 2005, A study on knowledge and adoption pattern improved sugarcane practices in sugarcane. M. Sc. (Agri) Thesis, Univ. Agric. Sci., Dharwad.

Reshmy, C., 1998, A study on sustainability of coconut and banana intercropping in Kerala-An analysis. M. Sc. (Agri.) Thesis, Univ. Agric. Sci., Bangalore, Karnataka (India).
Sidram, 2008, Analysis of organic farming practices in pigeon pea in Gulbarga district of Karnataka. M. Sc (Agri.) Thesis, Univ. Agric. Sci., Dharwad, Karnataka, (India).

Thippeswamy, R., 2007, A study on knowledge and adoption of plant protection measures in coconut cultivation by farmers of Chitradurga district. M.Sc. (Agri.) Thesis, Univ. Agric. Sci., Dharwad, Karnataka (India).

\section{How to cite this article:}

Nagesh, B., S.K. Meti and Maraddi, G.N. 2018. Knowledge Domain of Bt Cotton Cultivation Practices by the Bhoochetana Programme Beneficiaries. Int.J.Curr.Microbiol.App.Sci. 7(10): 3311-3317. doi: https://doi.org/10.20546/ijcmas.2018.710.383 